\title{
Constructing Practice-teaching System of Independent College Based on Characteristics of "3-1-6"
}

\author{
Zhen-Xin WANG ${ }^{1, a}$ \\ ${ }^{1}$ Tianjin University of Commerce Boustead College, Department of International Business \\ Administration, Tianjin 300384, China \\ awangzhenxin2012@126.com
}

\begin{abstract}
Keywords: Independent College, Characteristics of "3-1-6", the Practice-teaching System, Factor Analysis Method
\end{abstract}

\begin{abstract}
In order to solve the dilemma between employment difficulty of management majors in independent college and difficulties of hiring employees that many employers are facing, independent colleges should build a practice-teaching system that can promote students' employment ability comprehensively. Based on the investigation of 35 units in Tianjin, used factor analysis method to generalize four employment abilities which are employers concerned about. And take these abilities as the starting point and objective in talent cultivation of the practice-teaching system. The paper explored innovatively from six aspects: objective of practice-teaching, models, methods, platforms, assessment and teaching staffs. And then, the paper constructed the practice-teaching system with characteristics of “3-1-6".

Compared with the the first and the second batch of undergraduate, the employment situation of graduates from independent colleges is more serious. The majors of independent colleges are varied; however, the management professional is more typical of the research. Management majors should be highly application-oriented. Students should not only be familiar with the Professional theoretical knowledge of management, but also need to have the ability of learning, innovation and communication ${ }^{[1]}$. It become an urgent problem to enhanced the connection between the construction of Practice-teaching System and the employment market, and to innovate Practice-teaching System as well as to improve the students' employability ${ }^{[2]}$. And why did this dilemma happen in which the "hard to find a work" and "hard to find a worker" in the job market come together in parallel? This paper found the origin of the problem is: the traditional training mode is established training objectives and curriculum setting only by college, didn't take into account the needs of the employer, so, graduates didn't have the capacities that employers needed.

Therefore, it is need to consider four aspects when constructing the Practice-teaching System: take the capacities that employers needed as training objectives; satisfy three main bodies (employers, students, colleges); combine the internship and entrepreneurship with the independent internship more flexible; construct the Practice-teaching System from six aspects including teaching target, mode, methods, platform, evaluation and teaching staff construction.
\end{abstract}

\section{Analysis of employability by factor analysis method}

This paper selected 35 employers as survey objects, including institutions, state-owned enterprises, private enterprises, joint ventures and foreign-capital enterprises, related to 10 industries, including food and beverage industry, real estate, the Internet industry, retail, manufacturing industry, etc. The respondents were all heads of human resources. The human resources department is responsible for recruitment, training, salary and performance appraisal of the company, and has an in-depth understanding of the comprehensive ability and level of employees, and its evaluation is more objective and representative. HR managers evaluate the importance level of 13 employ-abilities. Used Likert scale to separate 5 levels from 1 to 5: 1 means "very unimportant”, 5 means "very important". Send out questionnaires to 35 employers in Tianjin city, all of these questionnaires were effective recovered. Cronbach's Alpha reliability coefficient of the questionnaire was 0.821 , as requested more than 0.8 indicates that the questionnaire was 
credibility. Through factor analysis, the 13 dimensions of employability reduced to four main factors: professional ability, general ability, communication ability and information processing ability.

\section{Prerequisite verification of factor analysis}

The method to test variables for whether it suitable for factor analysis is Bartlett Test of Sphericity (Bartlett ball Test) is and Kaiser - Meyer Olkin(KMO) Test. The approximate chi-square value of the Bartlett sphericity test was 108.139, Sig value was $0.001<0.01$, the KMO value was $0.788>0.7$, which was suitable for factor analysis.

\section{Factor extraction}

The principal component analysis was used to extract the factors, and then maximize the variance of each factor. When determine the number of factors, we usually applies Kaiser(1960) indicators or Eigen values. The Eigen values and variance contribution rate showed in table 1:

Table 1: Eigen values and variance contribution rate

\begin{tabular}{|c|c|c|c|c|c|c|c|c|c|}
\hline \multicolumn{10}{|c|}{ Total variance of interpretation } \\
\hline \multirow{2}{*}{$\begin{array}{l}\ddot{z} \\
\text { : } \\
\text { : } \\
\text { : }\end{array}$} & \multicolumn{3}{|c|}{$\begin{array}{c}\text { Initial } \\
\text { Eigenvalue } \\
\text { variance }\end{array}$} & \multicolumn{3}{|c|}{$\begin{array}{l}\text { Extract sum of } \\
\text { squares and } \\
\text { load variance }\end{array}$} & \multicolumn{3}{|c|}{$\begin{array}{l}\text { Rotational sum } \\
\text { of squares } \\
\text { variance }\end{array}$} \\
\hline & total & $\%$ & $\begin{array}{l}\text { accumu } \\
\text { lated \% }\end{array}$ & total & $\%$ & $\begin{array}{c}\text { accumul } \\
\text { ated \% }\end{array}$ & total & $\%$ & $\begin{array}{l}\text { accumu } \\
\text { lated \% }\end{array}$ \\
\hline 1 & 3.240 & 26.996 & 26.996 & 3.240 & 26.9 & 26.996 & 2.91 & 24.219 & 24.219 \\
\hline 2 & 1.871 & 15.592 & 42.589 & 1.871 & 15. & 42.589 & 1.809 & 76 & 39.294 \\
\hline 3 & 1.483 & 12.356 & 54.945 & 1.483 & 12.35 & 54.9 & 1.750 & 14.582 & 53.876 \\
\hline 4 & 1.146 & 9.547 & 64.492 & 1.146 & 9.547 & 64.492 & 1.274 & 10.616 & 64.492 \\
\hline
\end{tabular}

\section{Naming of Factor}

As shown in table 2. According to the factor composition of the rotation, we analysed the factors' composition and interpreted the factors' naming one by one.

Table2: Rotation component matrix

\begin{tabular}{lcccc}
\hline & \multicolumn{4}{c}{ composition } \\
\cline { 2 - 5 } & 1 & 2 & 3 & 4 \\
\hline Specialized knowledge levels & .746 & .298 & .111 & -.125 \\
Capability of professional software & .835 & -.017 & -.126 & .345 \\
application & & & & \\
Capability of continuous learning & .891 & .113 & -.034 & .066 \\
Ability to read and write in English & -.213 & .696 & -.005 & .404 \\
Ability of computer operating & .071 & .775 & .050 & -.177 \\
Performance of etiquette & .249 & .739 & .195 & .136 \\
Performance of self-confidence & .459 & .689 & .226 & -.071 \\
Ability to build and maintain & .017 & .080 & .716 & -.071 \\
relationships with others & .005 & .089 & .865 & .186 \\
Team work ability & .189 & -.037 & .856 & -.126 \\
Presentation skills & .095 & .063 & .076 & .874 \\
Capability of collecting and filtering & & & & \\
information & .089 & .098 & .356 & .831 \\
Ability to handle details & & & & \\
Extracting Method: principal component。 & & & \\
Rotation Method: varimax rotation with Kaiser standardization & &
\end{tabular}

a. The rotation converges after six iterations 。 
Factor 1: It is composed of 3 parts: "specialized knowledge levels ", " capability of professional software application" and" capability of continuous learning ". This factor reflected the requirements of students' professional quality, so we named it as "the professional competence factor".

Factor 2: It is composed of 4 parts: "ability to read and write in English", "ability of computer operating", "performance of etiquette", "performance of self-confidence". This factor reflected the requirements of the employers for some general working abilities of the students, so we named it as "common ability factor".

Factor 3: It is composed of 3 parts: "Ability to build and maintain relationships with others", "Team work ability", and "presentation skills". This factor reflected the requirements of the employers for abilities to communicate and coordinate of the students, so we named it as “communication skills factor".

Factor 4: It is composed of 2 parts: "capability of collecting and filtering information”, "ability to handle details". It reflected the requirements of the employer for the information processing ability of students, so we named it as "information processing ability factor".

\section{Innovative overview of the characteristics of "3-1-6"}

The characteristics of "3-1-6" had three-layer meaning: all three bodies (students, companies, colleges) are important; a combination (the internship and entrepreneurship with the independent internship) can be more flexible; the practice-teaching system innovates from six levels (teaching target, mode, methods, platform, evaluation and teaching staff construction).

\section{Three bodies are all important}

The practice-teaching System build by the paper changed the traditional practice of teaching subjects only for students and teachers to put companies in the process of talents cultivation ${ }^{[3]}$. the paper used the four employability modules which employer demand through above analysis as the basis when build the independent college management professional practice-teaching system.

\section{The combination is more flexible}

"The combination" is the way to combine the internship with students' independent practice and entrepreneurship. Through the survey, the paper found that firms are very welcome students to start their own business, and they hope that the practice time can be extended to more than 20 weeks. So, in the future, we can explore changes in the past school set concentration of summer and winter vacations and internship training scheme in the eighth semester. The paper particularly encourages students to carry out entrepreneurial activities and increases their practical courses and credits proportion which can cultivating students' entrepreneurial abilities.

\section{Innovation from six levels}

The paper analyses from six aspects, including practice teaching target, mode, method, platform, evaluation and teaching staff construction. According to employers' requirement, the paper explores the methods to promote students' practical abilities, and then constructs an innovative practice teaching system.

\section{Constructing of practice-teaching system for management majors of independent college}

\section{Setting the cultivating goal}

The cultivating goal for management majors of independent college is to cultivate application-oriented talents with professional knowledge and skills for enterprises and institutions. "Application-oriented" means that the practical ability should be emphasized, and students should meet the requirements of employers ${ }^{[4]}$. The traditional practice teaching aims to emphasize "hard 
practice" and focuses on the cultivation of practical ability and operation ability, but not emphasis on "soft practice" such as theoretical analysis or communication cooperation.

Through the investigation, this paper found that the employers want the students to have four abilities: professional ability, general ability, communication ability and information processing ability. Therefore, the paper set the cultivating goal based on the four abilities: consolidating and deepening the students learn professional knowledge during the practice teaching, cultivating students to master management specialized software and the abilities to use English and computer skillfully, making them good at communication, expression and cooperation, and have the ability of information processing and strong management practice.

\section{Designing teaching mode and method}

If the four abilities division is the answer to cultivating goal, the practical teaching mode and the implementation method are the important ways to achieve the goal. The paper divided practical teaching mode into six parts: experiment, curriculum design (in-class practice), practical teaching, internship, graduation thesis, course race or project.

\section{Experiment}

The experiment includes the application training and simulation based on the software, as well as the management role playing of physical props, sand table exercises, etc.Software application experiments mainly include operation information processing software (such as SPSS, Excel, etc.), report writing software (such as Word, PPT), etc., also include the study of literature retrieval using computer.

There are two kinds of software simulation experiments: process simulation and decision simulation. Process simulation refers to the application of computer software in the laboratory to simulate the process of real enterprise management decision-making, such as ERP production and operation system. This is a confirmatory experiment. Students should complete the operation according to the experimental plans and procedures. It is easy to learn, but lack of creativity. Decision-making simulation is to let students in the laboratory using computer software to operate the same type enterprise, under a predefined market environment, students can make production, marketing, finance, hr, strategy and so on comprehensive decisions in several analog years ${ }^{[5]}$.This simulation process is complex, which can help students to perceive the actual enterprise management decision-making process and improve the analysis and predict ability. Using sand table and other props as the simulation platform can be more vivid. Such as sand table simulation experiment: under the simulated competitive environment, students work to build five or six similar simulation company, using sand physical teaching tools to establish and develop the company by playing various management roles ${ }^{[6]}$.

\section{Curriculum Design (in-class practice)}

According to the cultivating goal, teachers should design a program for students needed to complete in team. Students using their theoretical knowledge and skills, and giving full play to the individual ability and the team spirit of cooperation to complete the project.

\section{Practical Teaching}

Including visit the enterprise, conduct market examination, special lectures and so on. Through the submission of the training report, students can increase their perceptual knowledge, enhance their interest in learning, and create more pressing needs for the future needs to make up for and enrich their professional knowledge.

\section{Internship}

Professional internship is an important part of management professional practice teaching, which basically adopts the combination of dispersion and concentration. It is generally includes cognition practice of enterprises and institutions and processes (basic cognitive), professional practice 
(particularly training) to a specific business management capabilities, graduation practice (including professional knowledge, communication and other comprehensive ability, focus on training). Through in-depth enterprise internship, students develop independent thinking ability, team spirit and communication skills. Through the survey, it is found that enterprises generally value students' internship experience and hope to extend the internship time.

\section{Graduation Thesis}

Graduation thesis is a summary of the four years' study of students, a comprehensive training in improving scientific research ability, and an important embodiment of the combination of theory and practice in cultivating goals. In the whole process of the graduation thesis writing, it can cultivate students a set of abilities, including find new perspective (find), preliminary grasp scientific research methods (assumption), column method, and improve students' ability of analysis problem solving and innovative ideas.

\section{Course Race or Project}

This part generally includes competitions, innovation and entrepreneurship programs and participation of teachers in scientific research projects. This is the most interactive activity in the practice teaching, and is a way to lead students to solve practical problems creatively and make teachers play a positive role in the form of comprehensive training.

\section{Establishing Teaching Platform}

\section{Laboratory Construction}

Laboratory is an important platform for practice-teaching. However, through the research, it was found that there are different opinions among enterprises and teachers in strengthening the practice teaching method. Enterprises value internship experience more, while teachers focus on experimental teaching. It also reflected that many laboratory facilities are obsolete, hardware and software are not keeping up with the times, and the gap between the laboratories' reality and enterprises' reality was big.

\section{Practice Teaching Base}

Independent colleges can establish practice teaching bases by signing internship base agreement with enterprises. It can draw lessons from the German "dual system" training mode. During four years of study, students can work in enterprises as a prospective employee both in summer and winter vacations, and their treatment is also consistent with the internship staff. After graduation they can be directly converted into formal employees .

\section{Virtual Network Platform}

Independent colleges can develop some experimental software to the campus network platform, so that students can use the Internet to practice. It also can put the courses online. It can be converted into class hours according to students' learning time, which can be converted into credits to motivate students to actively use the college network platform to study independently.

\section{Various Levels of Discipline Races}

It also can develop various discipline races, such as entrepreneurship competition, creative contest, English speech contest, mathematical modeling contest, etc. Students are encouraged to participate in competitions based on experimental software, such as sand table simulation contest.

\section{Selecting Test Style}

The paper suggest to make assessment style more diversification, evaluating the effect from several angles, such as class attendance, learning attitude, assignments and reports, the results show, expert review assessment and so on. 


\section{Construction of Faculty}

In order to improve the practice teaching level, teachers' level should be promoted first. The college should encourage practical teachers to continue to improve their professional titles and academic qualifications. At the same time, colleges should provide some opportunities for these teachers to reach out to enterprises and enhance their own practical ability.

\section{Conclusion}

The dilemma of "hard to find a work" and "hard to find a worker" in the job market from business administration management graduates of independent colleges is attracting more and more attention of the society. The paper analyzed four key abilities that enterprises concerned about based on the results of survey to employers, and set out the goal of practice teaching from this point. At the same time, the paper elaborated the practice teaching mode and the assessment method, and constructed the practical teaching system which embodies the characteristics of the students' ability in the business administration of the independent college. In addition, through the research of the differences between employers and college teachers', the paper provide improvement direction, method and enlightenment for college practical teaching, it is conducive to the improvement of practical teaching and the satisfaction of three subjects.

\section{Acknowledgement}

This research was financially supported by Tianjin education science planning project in 2017 "research on the formation mechanism and entrepreneurial practice system of independent college students" (Project Number: HE3023).

\section{References}

[1]MI Chuan-min, ZHANG Ting. Design of Curriculum Reform in Business Management Majors Based on Students' Ability Demand[J].Journal of Nanjing University of Aeronautics and Astronautics(Social Sciences), 2013,15(4): 90-93.

[2]ZHU Bai-qing. Construction of Practical Teaching System of Applied Undergraduate Business Administration [J].Hei long jiang Researches on Higher Education, 2009,(1): 163-165.

[3]CHEN Li-wan, CHEN Qiang, LI Hong-ping, WANG Ming-wei. Strengthening Practice and Promoting Ability, Creating Application-oriented Talents of to Satisfy Social Needs[J]. Research and Exploration in Laboratory, 2016.35(3):173-176.

[4]ZHANG Bao-chang, Liu Hai-feng. Building a comprehensive system of practical teaching and enhancing cultivation of practical capabilities [J].Experimental Technology and Management, 2012, 29(4):248-253.

[5]ZHANG Xin-rui. A Practice Teaching Mode Based on Training Objectives and Development of Professional Competency_ A Case Study of the Business Administration Major in Multiversities[J].Research and Exploration in Laboratory, 2012,31(9): 181-189.

[6]ZHAO Qiong. To Promote the Reform of Practical Teaching of Business Administration in Higher Vocational Colleges with "Sand Table Simulation” [J].Journal of Guangdong Polytechnic Normal University,2012,(4): 86-88. 